\title{
Analisis kebutuhan untuk meningkatkan kemampuan siswa SMP kelas VII dalam menganalisis perubahan iklim
}

\author{
Agnes Dwi Wulan Mahardika, Sugiyanto*, Muhammad Fajar Marsuki \\ Universitas Negeri Malang, Jl. Semarang No. 5 Malang, Jawa Timur, Indonesia \\ *Penulis korespondensi, Surel: sugiyanto.fmipa@um.ac.id
}

Paper received: 01-03-2021; revised: 15-03-2021; accepted: 31-03-2021

\begin{abstract}
Abstrak
Penelitian ini bertujuan untuk mencari solusi atas permasalahan kurangnya kegiatan siswa dalam menganalisis perubahan iklim. Metode yang dipakai adalah wawancara dengan guru serta siswa tentang kegiatan belajar siswa pada materi perubahan iklim dan kajian literatur. Berdasarkan hasil observasi wawancara yang dilakukan pembelajaran pada materi perubahan iklim belum mengarahkan siswa dalam kegiatan menganalisis. Peristiwa tersebut menunjukkan siswa belum menjadi pusat dalam pembelajaran. Dengan demikian maka didapatkan solusi untuk memperbaharui pembelajaran serta penambahan wawasan siswa dalam menganalisis perubahan iklim dengan menggunakan model PBL terintegrasi SETS.
\end{abstract}

Kata kunci: Perangkat pembelajaran; Model PBL; Integrasi SETS; Menganalisis perubahan iklim

\section{Pendahuluan}

Pembelajaran IPA adalah suatu proses interaksi antara guru dengan siswa dalam satu ruang lingkup yang menggunakan bahan ajar tentang gejala dan fenomena alam pada kehidupan sehari-hari. Pembelajaran IPA mendidik siswa mempelajari kehidupan mahkluk hidup, alam dan sekitarnya serta penerapannya di suatu ekosistem (S. Rahayu, dkk. 2019). Sistem pendidikan di Indonesia saat ini mengacu pada kurikulum 2013 (K-13) dengan pembelajaran IPA terpadu. Penerapan pembelajaran IPA terpadu disarankan menggunakan pembelajaran secara holistik, dengan kata lain pembelajaran yang disajikan mengkaitkan ilmu sains dengan berbagai bidang seperti lingkungan, teknologi, dan masyarakat (Setiawati \& Senam, 2016).

Pembelajaran yang dilakukan guru diharapkan dapat memotivasi siswa dalam belajar. Pengembangan dilakukan untuk membuat perangkat pembelajaran dengan model pembelajaran yang cocok sesuai karakteristik materi dan siswa. Strategi pembelajaran meliputi pemilihan model sekaligus pendekatan pembelajaran. Adapun pendekatan yang harus dilaksanakan dalam pembelajaran IPA adalah pendekatan saintifik (Narut \& Supradi, 2019), sedangkan model pembelajaran merupakan seluruh rangkaian peristiwa belajar yang dilakukan siswa dan kebanyakan guru hanya menjadi fasilitator untuk belajar siswa.

Kegiatan siswa dalam menganalisis materi pembelajaran IPA di sekolah masih tergolong kurang efektif khususnya pada materi perubahan iklim. Hal tersebut diketahui berdasar hasil wawancara kepada guru dan siswa mata pelajaran IPA di kawasan Malang Raya. embelajaran dilakukan dengan sebaik-baiknya akan tetapi pembelajaran yang dilakukan belum memotivasi siswa untuk lebih aktif dan semangat dalam kegiatan pembelajaran, sehingga diperlukan perombakan atas model pembelajaran yang digunakan dengan tujuan memperbaiki kefektifan kegiatan pembelajaran IPA khususnya materi perubahan iklim. 
Berdasarkan permasalahan tersebut maka dilakukan analisis kebutuhan mengenani strategi dan model pembelajaran untuk memeperbaiki keefektifan proses kegiatan belajar yang dilakukan guru dan siswa pada pokok bahasan materi perubahan iklim.

\section{Metode}

Metode yang digunakan untuk penelitian ini adalah wawancara dan kajian literatur tentang strategi dan model pembelajaran yang dijadikan solusi dalam memecahkan masalah sedikitnya waktu untuk pembelajaran, materi perubahan iklim yang disajikan bukan materi dasar, dan keaktifan siswa yang belum cukup untuk menganalisis perubahan iklim. Instrumen penilitan menggunakan tes wawancara. Wawancara dilakukan peneliti dengan guru IPA SMPN 4 Malang, guru IPA SMPN 8 Malang, guru dan siswa IPA SMPN 2 Pakisaji.

\section{Hasil dan Pembahasan}

Wawancara dilakukan dengan beberapa guru dan siswa mata pelajaran IPA, hasil dari wawancara beberapa guru IPA tersebut menunjukkan bahwa perangkat pembelajaran IPA khusunya materi perubahan iklim memiliki alokasi waktu kegiatan belajar yang cukup sedikit karena terpotong oleh kegiatan-kegiatan lainnya di semester genap, pembelajaran pada materi perubahan iklim diterapkan hanya mengkaitkan ilmu sains dengan lingkungan sehingga pembelajaran dilakukan kurang holistik, model pembelajaran yang digunakan merupakan model discovery learning (merupakan model pembelajaran yang disarankan dalam kurikulum 2013) yang pada implementasinya masih dominan dengan metode guru ceramah, kurang efektifnya pembelajaran membuat siswa kurang mengembangkan kemampuan menganalisis perubahan iklim, materi yang digunakan bukan materi dasar dari perubahan iklim.

Siswa berpendapat bahwa pembelajaran IPA merupakan pembelajaran yang membutuhkan konsentrasi tingkat tinggi. Beberapa siswa menyatakan kesulitan mereka dalam mempelajari hal-hal sains dan menyimpulkan bahwa pembelajaran IPA sangat sulit untuk dipahami. Selain itu, siswa merasa pembelajaran yang dilakukan kurang menarik dan membosankan sehingga siswa tidak mau berperan dalam kegiatan pembelajaran dengan artian lain siswa tidak banyak terlibat dan berinteraksi saat kegiatan belajar berlangsung. Hal demikian bertolak belakang dengan karakteristik pembelajaran IPA, dalam Permendikbud No. 22 Th. 2016 pembelajaran IPA bersifat aktif, interaktif, dan menyenangkan. Pembelajaran IPA dilakukan dengan menghubungkan ingatan siswa dengan pengetahuan baru yang akan dipelajari, dengan terlaksananya proses tersebut dapat meningkatkan kemampuan siswa dalam menganalisis materi pembelajaran yang diajarkan.

Hasil wawancara beberapa guru dan siswa menunjukkan bahwa kurang menarik serta kurang efektifnya metode dan model pembelajaran yang digunakan sehingga membutuhkan model pembelajaran yang lebih efektif dan menarik minat siswa dalam kegiatan pembelajaran IPA, khususnya pada materi perubahan iklim.

Hasil penelitian menurut Kurniawan (2016), tentang pembelajaran IPA dengan model pembelajaran PBL terintegrasi pendidikan karakter dapat melatih dan mengembangkan kemampuan kognitif siswa dalam menyelesaikan masalah. Penyelesaian masalah dilakukan dengan kemampuan kognitif siswa yang diantara lain seperti kemampuan menganalisis materi dengan menguraikan atau menghubungkan keterkaitan materi yang sedang dipelajari dengan memori yang ada dalam ingatan siswa. Hal demikian membuat siswa secara tidak langsung dapat meningkatkan hasil belajarnya baik secara afektif, kognitif, dan psikomotorik. 
Hasil penelitian menurut Zahra, dkk (2019), tentang pembelajaran sains yang diterapkan dengan pembelajaran SETS dapat mempengaruhi keterampilan proses sains siswa. Keterampilan proses sains siswa yang diuji dan diteliti meliputi: keterampilan: (1) mengamati materi ajar (2) mengukur materi ajar (3) memprediksi materi ajar (4) mengelompokkan materi ajar (5) mengiferensi materi ajar dan (6) mengkomunikasikan penyelesaian materi ajar. Meningkatnya keterampilan proses sains siswa mempengaruhi hasil belajar siswa.

Hasil penelitian menurut Amijaya, dkk (2018) tentang implementasi pembelajaran dengan menerapkan model inkuiri terbimbing pada pembelajaran IPA memberikan dampak positif terhadap hasil belajar siswa dan kemampuan berpikir kritis siswa. Hasil belajar siswa meningkat pada hasil kognitif yang menyebabkan siswa berhasil dalam: (1) mengingat pembelajaran (2) memahami pembelajaran (3) menerapkan pembelajaran (4) menganalisis pembelajaran dan (5) menciptakan solusi dalam pembelajaran. Kemampuan berpikir kritis siswa mengalami peningkatan yang lebih baik ketika pembelajaran didalam kelas diterapkan menggunakan model inkuiri terbimbing. Ketika pembelajaran berlangsung siswa diberikan kesempatan untuk mengembangkan kemampuan ilmiah siswa, dengan memberikan siswa kesempatan untuk mengeksplorasi kemampuan berpikir dalam menemukan solusi dari pembelajaran yang telah dilakukan.

Hasil penelitian menurut Van Gobel, dkk (2019) tentang penerapan pembelajaran IPA dengan model inkuiri terbimbing bervisi SETS yang memiliki pengaruh besar terhadap keterampilan proses sains siswa dan hasil belajar siswa. Model inkuiri terbimbing bervisi SETS meningkatkan keterampilan proses sains siswa yang meliputi 3 aspek, seperti: (1) tahap awal yang terdiri dari mengajukan pertanyaan, berhipotesis, dan menyusun kerangka percobaan (2) tahap pelaksanaan yang terdiri dari keterampilan menggunakan alat ilmiah, mengamati, dan mengklasifikasi hasil percobaan, serta (3) tahap akhir yang terdiri dari mempresentasikan hasil dan menarik kesimpulan hasil. Model inkuiri terbimbing bervisi SETS memberi pengaruh pada hasil belajar siswa pada penilaian afektif, psikomotorik, dan kognitif.

Hasil penelitian lainnya menurut Wijaya, dkk (2018) penggunaan model PBL integrasi SETS untuk materi pembelajaran IPA sangat mempengaruhi proses belajar siswa dan mengasah kemampuan siswa dalam berpikir kritis. Adapun indikator dari hasil penelitian model PBL terintegrasi SETS terhadap kemampuan berpikir kritis siswa adalah: (1) memfokuskan pertanyaan (2) menganalisis argumen (3) bertanya dan menjawab pertanyaan (4) mempertimbangkan kredibilitas sumber (5) membuat dan mempertimbangkan hasil (6) menentukan hasil (7) mendefinisikan istilah (8) mengidentifikasi asumsi (9) memutuskan suatu tindakan dan (10) menyimpulkan dan berinteraksi dengan orang lain. Pembelajaran IPA dengan menerapkan model PBL terintegrasi SETS menuntun dang mengarahkan siswa untuk menyelesaikan masalah dengan mengkaitkan ilmu sains dengan ilmu teknologi, sosial, dan masyarakat. Dengan demikian siswa mendapatkan solusi secara global dari permasalahan yang telah dikaji.

Berdasarkan hasil observasi wawancara dan kajian literatur maka didapatkan solusi atas permasalahan yaitu pembaharuan model pembelajaran untuk kegiatan menganalisis siswa dalam kegiatan pembelajaran terhadap materi perubahan iklim. Pembaharuan model pembelajaran yang sesuai untuk mendidik siswa dalam kegiatan menganalisis materi 
perubahan iklim adalah penerapan model PBL terintegrasi SETS. Model PBL dapat melatih kemampuan siswa dalam menganalisis materi IPA khususnya materi perubahan iklim, sedangkan integrasi SETS melatih siswa dalam mengeksplorasi pola piker siswa terhadap materi yang akan dipelajari serta mengaitkan permasalahan pada ilmu sains dengan bidang lingkungan, teknologi, dan masyarakat.

Karakteristik model pembelajaran PBL terdiri dari 5 perihal utama. Karakteristik PBL menurut Trianto dalam Adriadi dan Tarihoran (2016) adalah: (1) mempunyai sumber utama permasalahan (2) permasalahan yang diajarkan menggunakan masalah nyata (3) permasalahan diselesaikan dengan melakukan penyelidikan (4) menghasilkan karya dari hasil penyelidikan dan (5) memiliki daya kerjasama dengan teman sebaya guna membangkitkan motivasi belajar siswa.

Model pembelajaran PBL merupakan salah satu model inovatif, dimana kegiatan pembelajaran di kelas tidak hanya berfokus pada guru dan kegiatan belajar siswa tidak hanya monoton untuk mendengarkan atau menulis materi yang disampaikan guru. Guru akan memberikan suatu permasalahan dan memotivasi minat belajar siswa kemudian siswa akan menyelesaikan masalah tesebut dengan menggali informasi serta mengeksplorasi lingkungan sekitar dan kaitannya dengan kegiatan sehari-hari mereka. Penerapan model PBL mendidik siswa untuk berwawasan terbuka dalam menghadapi dan menyelesaikan suatu masalah baik di kelas maupun dikehidupan sehari-hari. Lingkungan belajar dengan model PBL memiliki sifat yang terbuka, berproses demokrasi, serta mendidik siswa untuk aktif dalam kegiatan pembelajaran (Syafriani, dkk. 2017). Dengan begitu penerapan integrasi SETS dapat membantu pembelajaran dengan model PBL yang bertujuan untuk membentuk individu yang berliteritas sains dan teknologi serta peduli terhadap masyarakat dan lingkungan (Aprianingtyas \& Sumadi, 2016).

Pembelajaran terintegrasi SETS turut mendukung karakteristik pembelajaran IPA yang diajarkan secara holistik. Penerapan pembelajaran SETS meningkatkan pola berpikir kritis siswa dengan mempelajari dan menggali informasi sesuai dengan topik yang telah diberikan oleh guru (Widiantini, dkk. 2017). Pembelajaran SETS melibatkan siswa dalam menanggapi dan menganalisis isu-isu aktual dan menghasilkan solusi terbaik dalam menyelesaikan hal tersebut. Penerapan SETS dalam pembelajaran IPA meningkatkan kemampuan siswa dalam menganalisis dengan menguraikan, membedakan, menghubungkan materi pembelajaran IPA khususnya materi perubahan iklim.

Karakteristik integrasi SETS terhadap pembelajaran PBL dalam materi sains sesuai dengan pendapat dari Son (2017) sebagai berikut: (1) pemberian materi sains pada proses pembelajaran (2) penghubungan materi sains dengan pemanfaatan pada aspek teknologi dan kepentingan masyarakat (3) pengarahan terhadap siswa untuk menganalisa efek positif dan negatif terhadap konsep sains yang diaplikasikan pada aspek teknologi (4) pembuatan kesimpulan konsep sains dengan aspek SETS secara keseluruhan dan pengaruhnya dalam kehidupan sehari-hari serta (5) pengarahan terhadap siswa untuk membangun kemampuan menyampaikan pendapat mengenai konsep sains yang dipelajari dan kaitannya dengan unsur SETS.

Penerapan model PBL terintegrasi SETS mengarahkan siswa dalam melakukan pembelajaran dengan mengasah berbagai kemampuan kognitif siswa. Kemampuan kognitif siswa berkembang membentuk kemampuan menganalisis. Dengan berkembangnya kegiatan 
siswa dalam menganalisis materi, dapat memudahkan siswa dalam menyelesaikan permasalahan pada materi ajar IPA khususnya perubahan iklim. Kemampuan menganalisis merupakan kemampuan pola pikir yang mengorganisir suatu permasalahan secara global dan menjadikannya secara khusus, begitu pula sebaliknya (Zubaidah, 2017). Indikator kemampuan menganalisis menurut Angelo dalam Zubaidah (2017) adalah: (1) kemampuan menguraikan (2) kemampuan mengidentifikasi (3) kemampuan menghubungkan (4) kemampuan membedakan (5) kemampuan memerinci (6) kemampuan membuat diagaram/grafik serta (7) kemampuan penggambaran masalah secara jelas secara verbal.

Berikut ini adalah tahapan dari model PBL menurut Mohamad Nur dalam Rusmono (2014) sebagai berikut:

Tabel 1. Tahapan Model PBL

\begin{tabular}{ll} 
Tahapan Pembelajaran & Aktivitas Guru \\
\hline Tahapan 1 & Menginformasikan tujuan pembelajaran, \\
Mengorganisasikan/ & mendiskripsikan kebutuhan logistik penting, dan \\
mengoientasikan siswa & memberikan motivasi siswa untuk menyelesaikan \\
terhadap masalah & masalah yang telah dipilih \\
\hline Tahapan 2 & Membantu siswa untuk mengelola dan mengatur \\
Mengelompokkan siswa & tugas belajar yang berhubungan dengan kasus \\
untuk meneliti/belajar & permasalahan yang telah diambil \\
Tahapan 3 & Mendorong siswa untuk mencari dan mendapatkan \\
Membantu & informasi yang sesuai, melaksanakan percobaan, \\
penyelidikan/investigasi & dan mencari solusi \\
mandiri dan kelompok & \\
Tahapan 4 & Membantu siswa untuk menyiapkan hasil karya \\
Mempresentasikan dan & seperti rekaman video, laporan, model-model, serta \\
mengembangkan hasil & membantu siswa untuk berbagi dan menyampaikan \\
karya/hasil penyelidikan & karya siswa \\
\hline Tahapan 5 & Membantu siswa merefleksi atas penyelidikan dan \\
Menganalisis dan & proses-proses yang siswa kerjakan \\
mengevaluasi proses & \\
pemecahan masalah &
\end{tabular}

Sumber:(Rusmono, 2014)

Model PBL sangat cocok untuk meningkatkan kemampuan siswa dalam menganalisis materi perubahan iklim. Integrasi SETS ditambahkan menuntun siswa untuk lebih mendalami materi dengan mengkaitkan ilmu sains dengan bidang teknologi, lingkungan, dan masyarakat. Penerapan PBL integrasi SETS tidak melatih siswa untuk menghapal saja, melainkan melakukan pembelajaran IPA penuh makna yang aktif dan efektif.

\section{Simpulan}

\subsection{Kesimpulan}

Berdasarkan permasalahan yang telah dibahas, penerapan model PBL terintegrasi SETS sangat dibutuhkan untuk melatih kemampuan siswa dalam menganalisis materi pembelajaran IPA khususnya perubahan iklim. Pembaharuan model pembelajaran ini dapat mengasah kemampuan siswa dalam berpikir tingkat tinggi dan berpikir kritis dalam menyelesaikan suatu permasalahan secara global dengan mengkaitkan ilmu sains pada berbagai aspek. 


\subsection{Saran}

Pembelajaran PBL terintegrasi SETS untuk menganalisis perubahan iklim harus disiapkan secara efektif sebelum pembelajaran dilaksanakan. Terutama pada materi yang akan diberikan, materi perubahan iklim bukan hanya pemanasan global alangkah lebih baiknya bagi guru menyiapkan materi-materi yang lebih dasar. Kegiatan belajar siswa dikembangkan dengan karakteristik PBL-SETS yang menarik dan memotivasi siswa agar semangat belajar dalam menyelesaikan topik permasalahan yang diberikan. Diperlukan penelitian lebih lanjut memperbaiki model pembelajaran yang diterapkan pada pembelajaran IPA khususnya materi perubahan iklim.

\section{Daftar Rujukan}

Adriadi, A. (2017). PEMBELAJARAN PROBLEM BASED LEARNING (PBL) DAN MOTIVASI SISWA TERHADAP HASIL BELAJAR PAI DI SMP NEGERI I CIRUAS-SERANG. SAINTIFIKA ISLAMICA: Jurnal Kajian Keislaman, 3(02), 145-168.

Amijaya, L. S., Ramdani, A., \& Merta, I. W. (2018). Effect of guided inquiry learning model towards student learning outcomes and critical thinking ability. J. Pijar Mipa, 13(2), 94-99.

Aprianingtyas, M., \& Sumadi, S. (2017). PENGARUH MODEL PEMBELAJARAN SETS (SCIENCE, ENVIRONMENT, TECHNOLOGY, AND SOCIETY) TERHADAP PRESTASI BELAJAR FISIKA POKOK BAHASAN TEKANAN. Compton: Jurnal Ilmiah Pendidikan Fisika, 3(2).

Kurniawan, H. E. (2016). Pengembangan Perangkat Pembelajaran IPA SMP Berbasis Problem Based Learning pada materi Getaran dan Gelombang. Jurnal Pendidikan Fisika dan Keilmuan (JPFK), 2(1), 16-28.

Narut, Y. F., \& Supardi, K. (2019). Literasi sains peserta didik dalam pembelajaran IPA di indonesia. JIPD (Jurnal Inovasi Pendidikan Dasar), 3(1), 61-69.

Rahayu, S., Harjono, A., \& Gunada, I. W. (2019). Pelatihan Penggunaan KIT IPA Bagi Guru dan Siswa SMP N 1 Sakra Lotim. Jurnal Pengabdian Masyarakat Sains Indonesia, 1(1).

Rusmono, S. P. D. P. B. (2012). Learning Itu Perlu Untuk Meningkatkan Porfesionalitas Guru. Bogor: Ghalia Indonesia.

Setiawati, I. K., \& Senam, S. (2015). Pengembangan perangkat pembelajaran ipa berbasis sets untuk meningkatkan scientific literacy dan foundational knowledge. Jurnal Inovasi Pendidikan IPA, 1(2), 178-190.

Son, R. S. S. (2017). Pembelajaran Bervisi Sets Model Problem Based Learning Pada Materi Daur Ulang Limbah. Scholaria: Jurnal Pendidikan Dan Kebudayaan, 7(3), 257-266.

Syafriani, D. (2017). Pembelajaran Problem Based Learning Untuk Menumbuhkan Sikap Demokratis Dan Meningkatkan Hasil Belajar Siswa Pada Materi Ikatan Kimia. School Education Journal Pgsd Fip Unimed, 7(1), 35-45.

Van Gobel, S. I., Rumape, O., \& Duengo, S. (2019). Pengaruh model pembelajaran inkuiri terbimbing bervisi sets terhadap keterampilan proses sains dan hasil belajar pada materi larutan elektrolit dan nonelektrolit kelas X SMA negeri 1 Gorontalo. Jambura Journal of Educational Chemistry, 1(1), 21-30.

Widiantini, N. N. A. S., Putra, M., \& Wiarta, I. W. (2017). Model pembelajaran sets (science, environment, technology, society) berbantuan virtual lab berpengaruh terhadap kompetensi pengetahuan IPA. Journal of Education Technology, 1(2), 141-148.

Wijaya, W. S., Feronik, T., \& Fairusi, D. (2018). Penerapan problem based learning berpendekatan SETS terhadap keterampilan berpikir kritis siswa. Jurnal Tadris Kimiya, 3(1), 94-103.

Zahra, M., Wati, W., \& Makbuloh, D. (2019). Pembelajaran SETS (Science, Environment, Technology, Society): Pengaruhnya pada Keterampilan Proses Sains. Indonesian Journal of Science and Mathematics Education, 2(3), 320-327.

Zubaidah, S. (2010, January). Berpikir Kritis: kemampuan berpikir tingkat tinggi yang dapat dikembangkan melalui pembelajaran sains. In Makalah Seminar Nasional Sains dengan Tema Optimalisasi Sains untuk memberdayakan Manusia. Pascasarjana Unesa (Vol. 16, pp. 1-14). 